\title{
Moulds and Ochratoxin A occurrence in Cola nitida fresh nuts after treatment by fungicide epoxiconazole and stored for several months in various containers
}

\author{
Nimaga Daouda ${ }^{1}$, Kouadio James Halbin ${ }^{2,}$, Nindjin Charlemagne ${ }^{1}$, Tetchi Fabrice Achille ${ }^{1}$, \\ Amani Georges \\ ${ }^{1}$ Dept. of Biochemistry and Tropical Products Technology, UFR STA, Nangui Abrogoua University 02 BP 801 Abidjan 02, Côte d’Ivoire \\ ${ }^{2}$ Dept. of Biochemistry and Microbiology, UFR Agroferesterie, University of Jean L. GUEDE, DALOA, Côte d'Ivoire
}

\section{Email address:}

daonimaga@yahoo.fr (Nimaga D.), jameshalbink@yahoo.fr (K. J. Halbin), charlemagne.nindjin@yahoo.fr (Nindjin C.), tetchifa@yahoo.fr (T. Fabrice), amanigeorges@yahoo.fr (G. Amani)

\section{To cite this article:}

Nimaga Daouda, Kouadio James Halbin, Nindjin Charlemagne, Tetchi Fabrice Achille, Amani Georges. Moulds and Ochratoxin A Occurrence in Cola Nitida Fresh Nuts after Treatment by Fungicide Epoxiconazole and Stored for Several Months in Various Containers. International Journal of Nutrition and Food Sciences. Vol. 2, No. 6, 2013, pp. 327-331. doi: 10.11648/j.ijnfs.20130206.20

\begin{abstract}
The conservation of fresh kolanuts produced in Côte d'Ivoire and intended for the export, poses a veritable problem for the farmers. After 2 or 3 months of storage, the stock of kolanuts dramatically diminished occasioning high loss of economic resources. The aim of the present study was to find strategies for the best conservation for long period by investigation in appropriated nature of container, temperature of storage and in a possible fungicide adequate for kolanuts. Three (03) containers namely traditional made from the leaves of Thaumatococcus daniellii (Benn.) Benth., polyvinyl chloride (PVC) container and perforated cardboard have been studied. The temperatures of storage investigated were $26^{\circ} \mathrm{C}$ and $29^{\circ} \mathrm{C}$ while epoxiconazole is used as the fungicide. Fungi and Ochratoxin A (OTA) occurrence have been taken as bio-indicators of kolanuts healthy. Fungi were isolated by using Potato Dextrose Agar (PDA) and standard laboratory methods while OTA was extracted with a methanol/3\% sodium hydrogen carbonate solution and purified using an immunoaffinity column prior to HPLC analysis with fluorescence detection. As results, the best temperature of storage could be $26^{\circ} \mathrm{C}$ and the container PVC had been found more efficient in fungi reduction in kolanuts when compared to traditional container made from leaves of Thaumatococcus daniellii (Benn.) Benth. In addition, OTA levels are stayed lows after 10 months of kolanuts storage. Moreover, the fungicide epoxiconazole was able to prevent Aspergillius flavus proliferation and retarded both Penicillium sp. contamination and OTA secretion in kolanuts until 6 months of storage. Taken together, the results suggested that a combination of the using of PVC container and fungicide epoxiconazole and $26^{\circ} \mathrm{C}$ as temperature of storage could improve significantly the conservation of fresh kolanuts for several months.
\end{abstract}

Keywords: Fresh Kolanuts-Storage, PVC Container, Temperature-26 ${ }^{\circ} \mathrm{C}$, Fungicide-Epoxiconazole

\section{Introduction}

Kolanuts are the cotyledons of some species of Cola, a genus of trees belonging to the family Sterculiaceae [1]. About 40 Cola species have been described in West Africa; however, the Cola species of economic importance are $C$. acuminata and C. nitida [2-5]. But, Cola nitida (vent.) Schott Endl. is the most important and widely, cultivated Cola spp. in Côte d'Ivoire and others main areas of tropical forest of West and Central Africa [6]. The bulk of Kola nuts produced in West Africa, in particular in Côte d'Ivoire is consumed locally and exported to Nigeria, Mali and
Burkina Faso as fresh nuts. The nuts are consumed for their stimulant properties and their taste and are traditionally used in Western and Central Africa during weddings funerals and ritual sacrifices. They are also used in the pharmaceutical and food industries to produce cardiac stimulants, laxatives, sedatives and sodas [7]. The Kola nut was one of the original ingredients used to make today's most famous soft drink, Coca-Cola. Today's, however, cola manufacturers do not use kola nuts in their secret recipes but rather rely on other ingredients. In Africa, the kolanut is chewed for its alkaloid properties (caffeine, kolanin, and theobromine), which dispel sleep, thirst, and hunger. There seems to be a slight preference for white kolanuts over red 
ones. Despite these multi-various uses of fresh kolanuts, relatively few investigations have been made into its microbial contamination and mycotoxins secretion such as ochratoxin A (OTA). Indeed, the growth of the mould could subsequently lead to production of OTA in kolanuts. Thus, the incidence of OTA in kolanuts has been previously reported [8].

OTA is a metabolite produced by a few moulds, mostly in the general Aspergillus and Penicillium that tend to colonize crops in the field or after harvest [8]. The constant ingestion of food or its products contaminated with OTA poses a potential threat to both human and animal health. OTA is reported to be carcinogenic [9], immunotoxic [10], genotoxic [11], immunosuppressive [12], and nephrotoxic [13]. There is also reduction in the nutritional quality of healthy kolanuts when attacked by mould. It had been reported a decrease of $42.9 \%$ of moisture content and $54.4 \%$ of crude protein and fat content in infected kolanuts by fungus when compared with the healthy ones [14]. High moisture content of $54-64 \%$ in kolanut enhances its susceptibility to fungus infection [15]. Subsequently, curing of kolanut at $30^{\circ} \mathrm{C}$ for 48 hours was recommended prior to storage [16]. But, since kolanuts are consumed in West Africa as fresh nuts, it is appeared important to find best strategies for their storage during several months without moulds colonization and mycotoxins secretion such as OTA. One way is to use efficient fungicides able to reduce or avoid moulds proliferation or mycotoxins secretion. Thus, the aim of the present study was to evaluate the incidence of fungicide treatment namely epoxiconazole (OPAL) on moulds and OTA occurrence in fresh kolanuts. The fungicide epoxiconazole disappeared in kolanuts only after 15 days or one month [17]. In parallel, the incidence of both container nature and temperature of storage was explored in order to propose alternative container to traditional container made from the leaves of Thaumatococcus daniellii and an adequate temperature of kolanuts storage.

\section{Materials and Methods}

\subsection{Fresh Kolanuts Treatment by Fungicide Epexiconazole}

Fresh kolanuts were obtained immediately after a 5-day curing period from kola merchants at Anyama city in the south of Côte d'Ivoire. The kolanuts samples were collected in a sterile polythene bags, labeled appropriately and assayed in-vitro within a week of collection. Healthy Kolanuts were firstly collected and abundantly washed by water and then treated by epoxiconazole (OPAL, 75g/l) obtained from BASF Corporation (USA) and diluted in water at concentration of $0.15 \mathrm{~g} / 1$. Then, fresh Kolanuts were conditioned in various containers such as traditional container i.e. a basket lined with leaves of Thaumatococcus daniellii (Benn.) Benth., (Container 1), polyvinyl chloride [PVC], (Container 2) and perforated cardboard (Container 3) containers. All containers were stored at temperatures 26 and $29^{\circ} \mathrm{C}$. Samples of kolanuts $(2 \mathrm{~kg})$ were collected from each container after 3, 6 and 10 months of storage for moulds identification and OTA analysis.

\subsection{Evaluation of Mycoflora}

The method of mycoflora evaluation is inspired from method previously described by [18]. During each investigation, 225 nuts obtained randomly from all packages were carefully observed with the naked eye for any evidence of mould infection. The cotyledons were then separated by hand and the state of the inner surfaces was also noted. Each cotyledon was subsequently cut into four pieces (about 10 by $18 \mathrm{~mm}$ each) and surface disinfected with a $2 \%$ aqueous solution of sodium hypochlorite for $2 \mathrm{~min}$. This was followed by washing with six changes of sterile distilled water before the four cotyledon-pieces were plated together equispaced on potato dextrose agar (PDA). The latter contained streptomycin sulphate $(5 \mathrm{mg} / \mathrm{ml})$ as an antibacterial antibiotic. Plates were incubated at $28^{\circ} \mathrm{C}$ for 5 to 10 days during which time the fungi that emerged were counted, isolated and identified with the aid of appropriate manuals.

\subsection{OTA Analysis}

\subsubsection{Reagents}

Standard solution of OTA $(100 \mathrm{ng} / \mathrm{ml})$, immunoaffinity columns (IAC) and saline pastilles, used to prepare the PBS buffer solution, were purchased from R-Biopharm (Lyon, France). The reagents were obtained from different commercial sources: methanol (Prolabo), acetonitrile/HPLC, toluene for analysis (Scharlau), sodium bicarbonate (Merck) and acetic acid (SDS).

\subsubsection{Extraction, Detection and Quantification of OTA}

The method used in the present study was previously described by [19]. Approximately $200 \mathrm{~g}$ of each kolanuts sample obtained randomly from various containers were thinly ground. Then, $15 \mathrm{~g}$ of each sample were put in a Waring blender bowl and $150 \mathrm{ml}$ of an aqueous solution (50: $50, \mathrm{v} / \mathrm{v})$ of methanol/sodium hydrogen carbonate $3 \%(\mathrm{~m} / \mathrm{v})$ were added and the mixture stirred for $2 \mathrm{~min}$. After decanting and filtering using Whatman paper no. 4, $11 \mathrm{ml}$ of filtrate was added to an equivalent volume of PBS buffer. The immunoaffinity column was pre-conditioned with $10 \mathrm{ml}$ of PBS buffer at a flow-rate of $3 \mathrm{ml} / \mathrm{min}$. Then, $20 \mathrm{ml}$ of extract was taken and loaded onto the immunoaffinity column at a flow-rate of $1-2 \mathrm{ml} / \mathrm{min}$. OTA present in the samples was captured by the antibodies contained in the agar suspension. The immunoaffinity column was washed with $20 \mathrm{ml}$ of PBS buffer to remove non-specific components. OTA was slowly eluted by $1.5 \mathrm{ml}$ of a mixture of acetic $\mathrm{acid} / \mathrm{methanol}(2: 98, \mathrm{v} / \mathrm{v})$ at a rate of $1-2 \mathrm{drops} / \mathrm{s}$. Then, the column was washed with $1.5 \mathrm{ml}$ of distilled water to obtain a final volume of $2.8 \mathrm{ml}$. After stirring, analysis was performed by HPLC Shimadzu HPLC LC 10AD VP equipped with a Shimadzu RF-10A XL fluorimetric detector and a Shimadzu C6R 8A integrator. HPLC analysis 
was carried out in an isocratic mode using fluorimetric detection at excitation and emission wavelengths of 333 and $460 \mathrm{~nm}$, respectively. The mobile phase was a mixture of acetonitrile/water/ glacial acetic acid (55: 43: 2, v/v) and the stationary phase was a C18 S5 ODS $2.5 \mathrm{~mm}(25 \mathrm{~cm} \mathrm{x} 4.6 \mathrm{~mm})$ column equipped with a pre-column. The peak of OTA in samples was identified by comparison with standards. OTA was quantified by measuring the peak area, taking into account the dilution performed during OTA extraction and purification.

\subsection{Statistical Analysis}

Data were expressed as mean \pm SEM. The occurrence of OTA in samples before and after the industrial treatments was compared using a Wilcoxon matchedpair test. Statistical significance was assumed at $\mathrm{p}<0.05$.

\section{Results}

\subsection{Fungi isolated from Kolanuts during the Storage}

Table 1. Mycoflora distribution in various containers (Container 1: traditional container; Container 2: polyvinyl chloride [PVC]; Container 3: perforated cardboard); Present (+), Absent (-).

\begin{tabular}{cccc}
\hline Fungi & Container 1 & Container 2 & Container 3 \\
\hline Aspergillus flavus & + & - & - \\
Aspergillus niger & - & + & + \\
Penicillium sp. & + & + & + \\
Muscor spinosus & - & + & - \\
Fusarium sp. & + & + & + \\
Alternaria sp. & + & - & + \\
\hline
\end{tabular}

Table 1 presented all fungi isolated from kolanuts after 3, 6 and 10 months of storage. Six (6) fungi isolates were cultured from the $C$. nitida samples. They include Aspergillus niger, A. flavus, Mucor spinosus, Fusarium sp., Penicillium sp. and Alternaria sp. Thus, Aspergillus flavus, Fusarium sp., Penicillium sp. and Alternaria sp. had been isolated from kolanuts in traditional container (leaves of of Thaumatococcus daniellii), Aspergillus niger, Mucor spinosus, Fusarium sp. and Penicillium sp. from kolanuts in
PVC container while Aspergillus niger, Fusarium sp., Penicillium sp. and Alternaria $s p$. were isolated from kolanuts in perforated cardboard as the third container.

\subsection{OTA Levels in Kolanuts during the Storage}

"Fig.1" summarized OTA secretion in fresh kolanuts during the storage. OTA was detected in kolanuts at 6 months of storage at values ranged from 0.5 to $1 \mu \mathrm{g} / \mathrm{kg}$. But, at 10 months of storage, the concentration of OTA increased $(2.45 \mu \mathrm{g} / \mathrm{kg})$ only in perforated cardboard (container 3$)$.

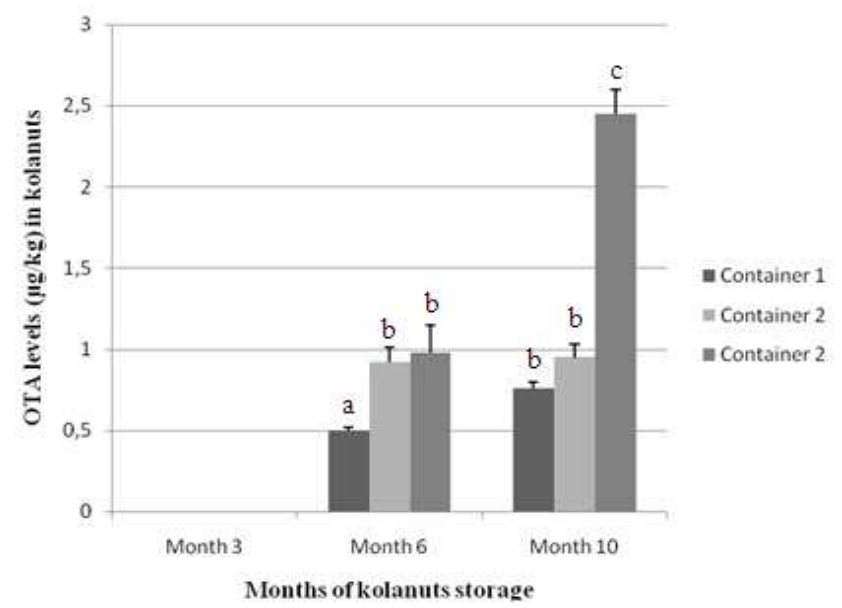

Figure 1. OTA levels during the storage (3, 6 and 10 months) of kolanuts in various containers (Container 1: traditional containner; Container 2: polyvinyl chloride container; Container 3: perforated cardboard). Results are given as mean $\pm S D$ from three independent experiments. (a), (b) and (c) used indicate the differences between OTA levels for the three containers, $p$ $<0.05$.

\subsection{Incidence of Temperature on Mycoflora Distribution and OTA Levels}

Table 2 presented impact of temperature $\left(26\right.$ and $\left.29^{\circ} \mathrm{C}\right)$ on moulds and OTA occurrence in kolanuts. The fungi isolated were Fusarium sp., Penicillium sp., Alternaria sp. at $26^{\circ} \mathrm{C}$ while those at $29^{\circ} \mathrm{C}$ were Fusarium sp., Penicillium $s p$. OTA secretion had been found more abundant at $29^{\circ} \mathrm{C}$ with levels of 2.45 and $3.56 \mu \mathrm{g} / \mathrm{kg}$ while OTA level maximum at $26^{\circ} \mathrm{C}$ was $0.76 \mu \mathrm{g} / \mathrm{kg}$.

Table 2. Incidence of temperature $\left({ }^{\circ} \mathrm{C}\right)$ on mycoflora distribution and OTA secretion in fresh kolanuts put in containers 1 and 2 (Container 1: traditional container; Container 2: polyvinyl chloride [PVC]). (*) indicates the differences between OTA levels following the temperature of storage, $p<0.05$. Limit of OTA detection $(L D)=0.02 \mu \mathrm{g} / \mathrm{kg}$; limit of OTA quantification $(L Q)=0.5 \mu \mathrm{g} / \mathrm{kg} ; \mathrm{n} . \mathrm{d}$. = not detected.

\begin{tabular}{|c|c|c|c|c|c|c|c|}
\hline \multirow[b]{2}{*}{ Containers } & \multirow[b]{2}{*}{ Temperature $\left({ }^{\circ} \mathrm{C}\right)$} & \multicolumn{2}{|c|}{ Month 3} & \multicolumn{2}{|c|}{ Month 6} & \multicolumn{2}{|l|}{ Month 10} \\
\hline & & Fungi & $\begin{array}{c}\text { OTA levels } \\
(\mu \mathrm{g} / \mathrm{kg})\end{array}$ & Fungi & $\begin{array}{c}\text { OTA levels } \\
(\mu \mathrm{g} / \mathrm{kg})\end{array}$ & Fungi & $\begin{array}{c}\text { OTA levels } \\
(\mu \mathrm{g} / \mathrm{kg})\end{array}$ \\
\hline \multirow{2}{*}{ Container 1} & 26 & Fusarium sp. & n.d. & Penicillium sp., & $<\mathrm{LQ}$ & Penicillium sp., Alternaria sp. & $0.76 \pm 0.04$ \\
\hline & 29 & Fusarium sp. & n.d. & Penicillium sp., & $0.5 \pm 0.04^{*}$ & Penicillium sp., & $2.45 \pm 0.7 *$ \\
\hline \multirow{2}{*}{ Container 2} & 26 & Fusarium sp. & $<\mathrm{LQ}$ & Fusarium sp. & $<\mathrm{LQ}$ & Fusarium sp. & $<\mathrm{LQ}$ \\
\hline & 29 & Fusarium sp. & n.d. & Penicillium sp., & $3.56 \pm 0.14 *$ & Penicillium sp., & $0.95 \pm 0.08^{*}$ \\
\hline
\end{tabular}




\subsection{Impact of Epoxiconazole on Mycoflora Distribution and OTA Levels}

Table 3 showed the influence of fungicide epoxiconazole on fungi and OTA occurrence in fresh kolanuts after 3, 6 and 10 monts of storage. The fungi isolated were Fusarium sp., Penicillium sp., Alternaria sp. for kolanuts treated by the fungicide while in kolanuts negative control, it had been found Aspergillius flavius and Penicillium sp. The secretion of OTA was similar with levels of $0.73 \mu \mathrm{g} / \mathrm{kg}$ for kolanuts negative control and $0.76 \mu \mathrm{g} / \mathrm{kg}$ for kolanuts treated by epoxiconazole.

Table 3. Impact of fungicide epoxiconazole used at concentration of $0.15 \mathrm{~g} / \mathrm{l}$ as recommended by manufacturer on mycoflora distribution and OTA secretion in kolanuts. Limit of OTA detection $(L D)=0.02 \mu \mathrm{g} / \mathrm{kg}$; limit of OTA quantification $(L Q)=0.5 \mu \mathrm{g} / \mathrm{kg} ; \mathrm{n.d}$. = not detected.

\begin{tabular}{|c|c|c|c|}
\hline $\begin{array}{l}\text { Storage } \\
\text { duration }\end{array}$ & & Kolanuts treated & Negative Control \\
\hline \multirow{2}{*}{ Month 3} & Fungi & Fusarium sp. & $\begin{array}{c}\text { Aspergillus flavus, } \\
\text { Penicillium sp. }\end{array}$ \\
\hline & $\begin{array}{l}\text { OTA levels } \\
(\mu \mathrm{g} / \mathrm{kg})\end{array}$ & n.d. & $<\mathrm{LQ}$ \\
\hline \multirow[b]{2}{*}{ Month 6} & Fungi & Fusarium $s p$ & Penicillium sp. \\
\hline & $\begin{array}{l}\text { OTA levels } \\
(\mu \mathrm{g} / \mathrm{kg})\end{array}$ & $<\mathrm{LQ}$ & $<\mathrm{LQ}$ \\
\hline \multirow{2}{*}{ Month 10} & Fungi & $\begin{array}{c}\text { Penicillium sp., } \\
\text { Alternaria sp. }\end{array}$ & Penicillium $s p$ \\
\hline & $\begin{array}{l}\text { OTA levels } \\
(\mu \mathrm{g} / \mathrm{kg})\end{array}$ & $0.76 \pm 0.04$ & $0.73 \pm 0.20$ \\
\hline
\end{tabular}

\section{Discussion}

In the present study, fungi and OTA occurrence have been taken as bio-indicators of healthy kolanuts. Thus, we have evaluated the impact of several parameters involved in fresh kolanuts storage such as the nature of container and the temperature of storage and fungicide used on fungi and OTA occurrence.

The abundance of fungi and OTA occurrence in kolanuts had been previously demonstrated $[8,17,18,20]$ and confirmed in the present study. Indeed, our results showed several fungi species isolated from fresh kolanuts including Aspergillus niger, A. flavus, Mucor spinosus, Fusarium sp., Penicillium sp. and Alternaria sp. but, Fusarium sp. and Penicillium sp. were the major species. Similar findings have been previously reported in Nigeria, one country of West-Africa [17] where about ten fungi species had been isolated namely Botryodiplodia theobromae, Fusarium pallidoroseum, F. moniliforme, F. cavispermum, F. oxysporum, Aspergillus niger, A. fumigatus, A. flavus, A tamarii, A. orchraceus, Paecilomyces variotii and species of Rhizopus spp. and Penicillium such as Penicillium funiculosum $[8,18,20]$. It is well known under some eco-physiological conditions, these fungi species can abundantly produce major mycotoxins aflatoxins, ochratoxins, fumonisins or zearalenone in food. Thus, it had been reported occurrence of aflatoxins and ochratoxins in kolanuts from Nigeria at levels ranged from 5 to $160 \mathrm{ppb}$ for aflatoxins [18] and 0.8 to $65.3 \mu \mathrm{g} / \mathrm{kg}$ for OTA [8]. Despite the low levels of OTA found in the present study (0.02 to $3.65 \mu \mathrm{g} / \mathrm{kg}$ ), our results confirmed such data previously reported on OTA in kolanuts [8]. OTA being known as one of major contaminants found in kolanuts so take fungi and OTA occurrence in kolanuts as safety criteria or bio-indicators of healthy kolanuts is logically justified.

The influence of container nature on both moulds and OTA occurrence in fresh kolanuts during the storage had been evaluated. Among the three (3) containers used in the present study, the perforated cardboard had not been found as suitable container for kolanuts storage for a long period. After, 10 months of storage, OTA had been found at concentrations higher than $2 \mu / \mathrm{kg}$ which were alarming since fresh kolanuts were directly consumed by the African population without serious treatment post-storage. The traditional container made from leaves of Thaumatococcus daniellii (Benn.) Benth., is known as the main container used in Côte d'Ivoire. After 10 months of storage, the concentrations of OTA were $0.73-0.76 \mu \mathrm{g} / \mathrm{kg}$ so significantly low as compared to those found with the perforated cardboard. For the PCV container, OTA levels remained low $(0.95 \mu \mathrm{g} / \mathrm{kg})$ at 10 months of storage and were not significantly different to those found with traditional container. Taken together, when considered "OTA occurrence" as safety criteria, traditional container made from leaves of Thaumatococcus daniellii (Benn.) Benth. and PVC container were best container nature for fresh kolanuts storage. But, the occurrence of Aspergillius flavus in kolanuts stored in traditional container could be alarming since A. flavus is known as aflatoxins main producer [21]. Thus, in future investigations, aflatoxins occurrence must be considered as supplementary as safety criteria in order to enrich solutions for the problematic of fresh healthy kolanuts storage in Côte d'Ivoire.

The incidence of temperature had been evaluated and our results revealed that $26^{\circ} \mathrm{C}$ was temperature suitable to reduce or prevent occurrence of both fungi and OTA in fresh kolanuts. Despite their presence in kolanuts, Penicillium sp. and Alternaria sp. seemed not to produce OTA abundantly at $26^{\circ} \mathrm{C}$ when compared to temperature at $29^{\circ} \mathrm{C}$. These differences in mycotoxins production resulting from variation of temperature had been observed for both containers used to store kolanuts for 3, 6 and 10 months. It appeared probable in the present study that the temperature optimum of fungi proliferation and OTA secretion in kolanuts was near $29^{\circ} \mathrm{C}$. Indeed, in laboratories several authors use 28 or $29^{\circ} \mathrm{C}$ as temperature suitable for moulds proliferation and mycotoxins secretion [18].

The pertinence of fungicide use in kolanuts storage had been evaluated in the present study with the fungicide epoxiconazole (OPAL). When considered OTA occurrence in kolanuts as bio-indicator, the efficiency of the fungicide epoxiconazole had been observed. Indeed, at 3 and 6 months of storage, OTA was already detected in kolanuts negative 
control but not in those treated by the fungicide. In addition, the epoxiconazole not only allowed avoiding the proliferation of Apergillius flavus which was occurred in negative control but also retarded the contamination of Penicillium sp. until 6 months of storage. Since Apergillius flavus is the major producer of aflatoxins [21], the fungicide epoxiconazole could be one efficient way for reduction of mycotoxins in kolanuts, particularly aflatoxins. In conclusion, the present study is a progress in strategies of mycotoxins, in particular OTA reduction in fresh kolanuts during the storage. The best temperature of storage could be $26^{\circ} \mathrm{C}$ and the container PVC had been found more efficient in fungi reduction in kolanuts when compared to traditional container made from leaves of Thaumatococcus daniellii (Benn.) Benth. In addition, OTA levels are stayed lows after 10 months of kolanuts storage. Thus, the PVC container could be an alternative efficient for the fresh kolanuts storage instead of leaves of Thaumatococcus daniellii (Benn.) Benth. But, the best is to combine the use of PVC container with a temperature of storage at $26^{\circ} \mathrm{C}$ and the treatment of kolanuts by the fungicide epoxiconazole for an appropriated response to the difficult fresh kolanuts conservation during a long and reasonable period.

\section{Acknowledgements}

This research was supported by grant from the FIRCA (Fonds interprofessionnel pour la recherche et conseil agricoles)-Conservation des noix de cola en Côte d'Ivoire.

\section{References}

[1] J.W. Purseglove, "Tropical Crops: Dicotyledons", Longman, Singapore 1974, pp. $564-570$.

[2] T. Quarcoo, “A Handbook on Kola”, CRIN, Ibadan, Nigeria, 1973.

[3] A. M. Daramola, Insect Pests of Cola in Nigeria (Research bulletin), vol. 3, CRIN, Ibadan, Nigeria, 1978.

[4] A.M. Daramola, "The biology of the kola weevils Balanogastris kolae on Cola acuminata and C. Verticilata", Insect Science and Its Application, 1981, Vol 2, pp. 201-205.

[5] A.M. Daramola, "Studies on the control of Kolanut weevils. Balanogastis kolae and sophrorhinus $\mathrm{Sp}$ (coleopteran curculionidae)", Tropical Stored Products Information, 1983, Vol 46, pp. 11-16.

[6] O. Nzekwu, "Kola nut. Nigeria Magazine”, 1961, Vol 7, pp. 298-305.

[7] N. E. Egbe and O. Sobamiwa, "Utilization of cocoa, kola, coffee, cashew and tea in Nigeria," in Progress in Tree Crop Research, pp. 217-224, CRIN, Ibadan, Nigeria, 1989.
[8] L.N. Dongo, K. Manjula and B. Orisajo, "Occurrence of ochratoxin A in Nigerian kola nuts", African Crop Science Conference Proceedings, 2007, Vol 8, pp. 2133-2135.

[9] E.E. Creppy, "Update of survey, regulation and toxic effects of mycotoxins in Europe", Toxicol Lett, 2002, Vol 127, pp. 19-28.

[10] H.D. Haubeck, G. Lorkowski, E. Koelsch and R. Roeschenthaler, "Immunosuppression by ochratoxin A and its prevention by phenylalanine", Applied and Environmental Microbiology, 1981, Vol 41, pp. 1040-1042.

[11] S. Obrecht-Pflumio, T. Chassat, G. Dirheimer and D. Marzin, "Genotoxicity of ochratoxin A by almonellamutagenicity test after bioactivation by mouse kidney microsomes. Mutation Research”, 1999, Vol 446, pp. 95-102.

[12] K. Mayura, J.F. Edwards, E.A. Maull and T.D. Phillips, "The effects of ochratoxin A on postimplantation rat embryosin culture", Archives of Environmental Contamination and Toxicology, 1989, Vol 18, pp. 411-415.

[13] M. Castegnaro, H. Bartsch, and I. Chernozemsky, "Endemic nephropathy and urinary tract tumors in the Balkans", Cancer Research, 1987, 47, pp. 3608-3609.

[14] S.O. Agbeniyi and M.S. Ayodele, "Effect of storage moulds on the nutritional quality of kolanuts in Nigeria", Pakistan Journal of Nutrition, 2010, Vol 9, pp. 512-515.

[15] D.B.A.Ogutuga, "Chemical composition and potential commercial uses of kola nuts Cola nitida (Vent.) Schott \&Endlicher", Ghana Journal of Agricultural Science, 1975, Vol 8, pp. 121-125.

[16] S.O. Agbeniyi and B. Fawole, "Effect of curing and pre-storage dip treatments on the control of storage mould of kola nuts", European Food Research and Technology, 1999, Vol 208, pp. 47-49.

[17] D. Nimaga, J.H. Kouadio, C. Nindjin, F. Tetchi and G. Amani, "Strategies of kolanuts conservation"- FIRCA Project report, unpublished.

[18] L.O. Adebajo and O.J. Popoola, "Mycoflora and mycotoxins in kolanuts during storage", African Journal of Biotechnology, 2003, Vol 2 pp. 365-368.

[19] P. Manda, D.S. Dano, J.H. Kouadio, A. Diakité, B. Sangaré-Tigori, M.J.M. Ezoulin, A. Soumahoro, A. Dembele and G. Fourny "Impact of industrial treatments on ochratoxin A content in artificially contaminated cocoa beans", Food Additives \& Contaminants: Part A., 2009, Vol 26, pp. 10811088.

[20] D.O. Adeniyi and O.O. Kolawole, "Incidence of mycoflora complexes on retail kolanuts (C. nitida and C. acuminata) in North Central Nigeria", Journal of Applied Biosciences, 2012, Vol 56, pp. 4075- 4079.

[21] M.A. Klich, "Aspergillus flavus: the major producer of aflatoxin”, Mol Plant Pathol, 2007, Vol 8, pp.713-722. 